\title{
Trajectories of social democracy in the Baltic countries: choices and constraints ${ }^{1}$
}

\author{
LIUTAURAS GUDŽINSKAS
}

\section{sciendo}

Politics in Central Europe (ISSN: 1801-3422)

Vol. 16, No. 1

DOI: 10.2478/pce-2020-0010

\begin{abstract}
This article focuses on social democratic parties in the Baltic states. The evolution of the democratic left in these countries deviates from more researched cases of social democratic parties in the Visegrád countries. Although the Lithuanian Social Democratic party (LSDP) had been developing in a similar way to its counterparts in Hungary, Poland and Czechia, its efforts to rebound after a crushing defeat in the 2016 parliamentary elections have proved to be far more successful. Meanwhile, Estonian and Latvian Social Democrats from the outset had to compete under the prevalence of right-wing parties in highly heterogenous societies. However, despite similar initial conditions, their eventual trajectories crucially diverged. Hence, a research puzzle is double: how to explain LSDP's deviation from similar Visegrád cases, and what are the main factors that led to the differentiation of Estonian and Latvian social democratic parties? While the current research literature tends to emphasise structural and external causes, this paper applies an organisational approach to explain the different fortunes of the democratic left in the Baltic countries as well as other East-Central European states.
\end{abstract}

Keywords: Baltic states, social democratic parties, party presidentialisation.

1 The research is funded by the European Social Fund under No 09. 3. 3-LMT-K-712-02-0165 'Development of Competencies of Scientists, other Researchers and Students through Practical Research Activities' measure. Its first version was presented at IPSA's conference in Brisbane, Australia, July 21-25, 2018. 


\section{Introduction}

Since the global financial crisis in 2008, there has been an almost ubiquitous decline of electoral support for the centre-left parties in the European Union (EU) - the process itself intrinsically linked with global political fluctuations started in the 1980s. While most analysts concentrated on the fortunes of social democracy in Western Europe, the development of social democratic parties in East-Central Europe (ECE) has been less researched and mostly focused on the Visegrád countries.

There are, however, at least three reasons why it is worth studying social democratic parties in the post-communist EU member states. Firstly, it denotes a broader category of post-communist parties. In many ECE countries, Social Democrats are among the most established parties with particular ideological aspirations in overly fluctuating post-communist politics. Secondly, having in mind challenges that have been faced by Social Democrats in Western Europe since the 1980s, it is worth it to see how these trends manifest in the post-communist part of Europe. And, thirdly, a more general motive derives from an observation that Social Democrats historically were a vital moving force in establishing and advancing democracy in Europe and beyond it. Therefore, status and current trends of these parties in the ECE countries is an important dimension to evaluate the prospects for democracy in the region.

The case of the Baltic countries is unique because of their highly securitised political systems. Securitisation, mostly stemming from perceived threats from Russia and vivid memories of the fifty year Soviet occupation, both supports and obstructs continuity of the democratic left in the Baltics. On the one hand, it restricts right-wing populist forces that usually compete with centre-left parties for the support of more socially conservative voters. In contrast with such cases as Poland and Hungary, where initially the social democratic tradition was arguably the strongest among ECE countries acceding to the EU, a more pronounced security dimension of the Baltic party politics restricted the rise of right-wing populism. On the other hand, it has shaped these countries in a direction contrary to aspirations of Social Democrats. Challenges are multiple - ranging from difficulties of integrating ethnic minorities to lack of attention on welfare issues to efforts by external actors to influence the domestic agenda of these states.

The article is divided into the following sections. Firstly, I will provide a theoretical framework to present possible explanations for the different fortunes of social democracy in ECE. Secondly, I will discuss how social democratic parties in the Baltic countries have developed in these circumstances.

In the latter empirical part, I will apply a methodological strategy of paired comparisons with a greater focus on its process-tracing qualities (Tarrow 2010). I will firstly explore the Lithuanian case, in which Social Democrats were one of the dominant forces since the country regained independence. Against this 
background, I will later jointly analyse the Estonian and Latvian cases as the most similar systems. In the concluding part, I will try to generalise common traits of all three cases, which might be subsequently investigated in other ECE countries and beyond them.

In the text I will use the terms of social democracy, centre-left and democratic left interchangeably. Also, I will put aside normative discussions about whether Social Democrats in the region genuinely belong to the political left. Although they are distinguished by certain organisational and ideological differences from Western European counterparts, we should not take it as an argument to disqualify them. Instead of looking for a single definition of a centre-left (social democratic) party, it is more reasonable to acknowledge diversity within the social democratic parties' family (Schmidt 2016; Keman 2017). Therefore, I have chosen two primary criteria to classify a post-communist party as social democratic. Firstly, it is a party that through mergers or re-founding is connected with its inter-war predecessors. Secondly, it is a party that has formal relations with the Party of European Socialists (PES) - either being its member or observant.

\section{Theoretical framework}

In contrast with an established research tradition on trends of social democracy in Western Europe, comparative analyses of social democratic movements in ECE countries are scarcer. Nevertheless, there have already been several phases of research on ECE Social Democrats in correspondence with the main issues of their development at a certain time. Scholars focused on the challenges for social democracy in the region during the first decade of the post-communist transformation (Coppieters, Deschouwer, Waller 1994; Cook, Orenstein and Rueschemeyer 1999; Dauderstädt 1999; Gerrits 2002), on the communist successor parties that rebranded themselves as the representatives of the democratic left (Orenstein 1998; Bozóki and Ishiyama 2002; Grzymala-Busse 2002; Curry and Urban 2003; Dauderstädt 2005), and on relations between Social Democrats in the region and the broader family of this political ideology (Hough, Paterson and James 2006; Hloušek and Kopeček 2010; Holmes and Lightfoot 2011; Cabada, Hloušek and Jurek 2014). Most recently, studies of ECE social democratic parties concentrate on their decline that has become particularly acute since the global financial crisis in 2008 (De Waele and Soare 2011; Vachudova 2015; Ágh 2018; Grzymala-Busse 2019).

According to Jean-Michel De Waele and Sorina Soare, centre-left parties in the region suffer from a lack of civic participatory culture and absence of robust intermediary organisations as well as from squeezing between EU requirements and satisfying national and local transitional needs (De Waele and Soare 2011).

Milada Anna Vachudova (2015) singles out corruption scandals that have struck political systems in ECE. Although the scandals affected not only Social 
Democrats, these parties were much more vulnerable due to a widespread association of the left with the communist past. Conservative societal attitudes towards minorities' rights, according to the author, is another factor that complicates the situation of the democratic left in the region. The more Social Democrats in ECE declare and support liberal positions regarding issues of human rights, self-expression and tolerance, the more they alienate voters of lower-income and socially conservative dispositions (Vachudova 2015: 65-66).

Meanwhile, Attila Ágh (2018) has systematically explored the incongruity of ECE social democratic parties' principles and their actual policies as a background for their eventual decline in many countries of the region. According to Ágh, due to the failure of democratisation and Europeanisation to improve social security within broader societal strata, we may observe a gradual shift from neoliberalism towards authoritarian neopopulism. This process also signifies the change in the power balance between the left and the right forces. By the late 2000s, the continued socio-economic crisis weakened the left, gradually making its narrative about Social Europe non-reliable. A mass sliding to the right and even to the extreme right began, as the nationalist and conservative forces overtook the leftist promises for solving social issues and protecting people from poverty. They did that by arguing that outside forces caused the failure of catching-up, which in general meant increasingly Eurosceptic rhetoric (Ágh 2018: 20).

The aforementioned accounts present a comprehensive list of structural or external factors that make the prospects for the democratic left parties in the region rather bleak. Nevertheless, one should bear in mind an insight made by Herbert Kitschelt from his pioneering study of the transformation of social democracy in Western Europe in the 1970-1980s that structural developments 'are not the primary and direct cause of social democratic political fortunes' (Kitschelt 1994: 281). In his words, 'political parties are not prisoners of the external societal environment and the distribution of citizens' political preferences; rather, their electoral trajectory and legislative power depends on internal conditions in the arena of party competition, inside party organization, and in their own political discourse, all of which affect their strategic choices in appealing for popular support' (Ibid).

A recent explanation of the breakdown of Hungarian and Polish ex-communist social democrats provided by Anna Grzymala-Busse partially addresses this research lacuna. According to the author, the main causes of the fiasco in these parties directly stem from their expansive development during first fifteen years of post-communist transformation. At the outset, the Polish Left Democratic Alliance (Sojusz Lewicy Demokratycznej, SLD) and Hungarian Socialist Party (Magyar Szocialista Párt, MSZP) successfully transformed themselves from former ruling parties of the communist regime into moderate centre-left forces and were able to win substantial electoral support by emphasising their competence and professionality. However, their development was not perfectly 
sustainable. On the one hand, the image of competence was hard to retain in the circumstances of complicated regime transformation. On the other hand, both parties struggled to cope with the exponential increase of party membership while their administrative capacities largely remained intact. On the contrary, it led to decentralisation and the emergence of 'local barons', internal disagreements and public accusations of corruption. Against this background, the reputation of SDL and MSZP as united, disciplined and competent political organisations was greatly damaged, which eventually led to their collapse and further fragmentation (Grzymala-Busse 2019).

However, to have a full picture of the decay of those formerly prevailing left-centre forces in their countries, we also need to consider the organisational development of their main rivals such as Fidesz in Hungary and 'Law and Justice' (Prawo i Sprawiedliwość, PiS) in Poland. In both cases, there is a high degree of power centralisation and consolidation in the hands of their leaders - Viktor Orbán (Enyedi 2005) and Jaroslaw Kaczynski (Bucur and McMenamin 2015) respectively.

We may observe a similar process in the Czech Republic. Although its Social Democrats (Česká strana sociálně demokratická, ČSSD) did not emerge from the communist regime unlike their Hungarian and Polish counterparts, they experienced a comparable fate in disastrous parliamentary elections in 2017. Despite a relatively good economic performance during the premiership of their leader Bohuslav Sobotka from 2013-2017, ČSSD unity suffered from various internal disagreements and divisions (Perottino and Polášek 2013; Kudrnáč and Petrúšek 2018; Cabada 2015) as well as by unwelcome interventions by president Miloš Zeman, their former disgruntled leader (Hloušek 2014). Moreover, like in Hungary and Poland, fragmented Czech Social Democrats had to confront a much more centralised ANO led by billionaire Andrej Babiš whose way of ruling the party resembles the top-down management of a business company rather than chairing a democratic political organisation (Kopeček 2016; Hloušek and Kopeček 2019).

Among social democratic parties in the Visegrád countries, only Slovakian SMER has so far avoided a similar breakdown. However, from the outset it has been highly centralised under the rule of Robert Fico (Malova 2013; Grzymala-Busse 2018) which makes it organisationally more akin to likewise presidentialised ANO, Fidesz and PiS than to its social democratic counterparts in the region.

The observed trends that highly centralised parties are becoming prevalent in the Visegrád countries - and more broadly in East-Central Europe - echoes developments in Western Europe. As Peter Mair noted in his last book before his untimely death, Western European democracies experience a gradual 'hollowing-out' caused by a double failure of parties to attract disenchanted voters and serve their leaders in advancing their executive careers (Mair 2013). Likewise, Thomas Poguntke and Paul D. Webb denote party presidentialisation 
as the 'hollowing-out of party government'. The main drivers of this European-wide process are internationalisation of politics and growth of state as well as media change and erosion of cleavages, both of which also induce parallel patterns of political personalisation (Poguntke and Webb 2018: 194).

In East-Central Europe, those trends, however, are likely to be even more pronounced as their democracies were to a large extent 'hollowed-out' from the very start, and after joining the EU they became even more intensified (Greskovits 2015). For most social democratic parties in the region, it has poised an acute challenge, especially if they originally evolved as relatively diffused and inherently fragmented organisations. To follow a genetic model of party organisation proposed by Angelo Panebianco (1988), if a party was created by diffusion rather than penetration, it will struggle to adapt itself to the challenges stemming from party presidentialisation (Passarelli 2015).

Development of social democratic parties in the Baltic states, however, presents an interesting case of deviation from the aforementioned trends in the Visegrád countries. Firstly, the Lithuanian Social Democratic party (Lietuvos socialdemokratu partija, LSDP) developed in a similar fashion to MSZP, SDL and ČSSD, i.e. through territorial expansion and relative decentralisation. They also experienced a humiliating defeat in parliamentary elections in 2016 against the centrist-populist Farmers and Greens - a 'business-firm' party single-handedly run by agro-tycoon Ramūnas Karbauskis. Yet, unlike their Visegrád counterparts, LSDP has managed to bounce back and remain one of the main political forces in the country. Meanwhile, the Estonian and the Latvian Social Democrats have never managed to run the government and thus have not experienced a significant expansion of their party membership. Nevertheless, despite their similar initial conditions they have evolved in completely different directions.

The theoretical premises discussed above allow us to raise an organisational explanation of all three Baltic cases. Namely, in order to survive, the Lithuanian Social Democrats had to implement internal reforms that enhanced their presidentialisation. On the other hand, the Farmers and Greens themselves should have experienced fragmentation problems, which would have limited their competitive advantage over their main rivals. Speaking about differentiation between the paths of the Estonian and Latvian Social Democrats, voluntary decisions of party leadership concerning their brand and identity should have played a major role in shaping their future.

\section{Trajectories of the Social Democrats in the Baltics}

Given the high salience of national security in Baltic politics, their party systems have also taken a somewhat different shape than in other countries in the region. In most ECE countries, we observe that the transformational division (communism versus anti-communism) is losing its relevance prominent in the 
1990s. Meanwhile, other cleavages such as a socio-economic one or a pro- vs anti-EU stance are becoming increasingly more prominent (Cabada, Hloušek and Jurek 2014: 99). However, it is not the case in the Baltic states.

In Lithuania, the communism vs anti-communism division still is the most crucial dimension of party competition (Ramonaite et al. 2014, Jastramskis et al. 2018). Meanwhile, in both Latvia and Estonia, the ethnic-linguistic divide remains a fundamental cleavage, although in Estonia it is somewhat overshadowed by the communism vs anti-communism clash (Saarts 2011). While these two cleavages have their mutual differences, both of them, against the background of the post-independent Baltic countries, should be treated as geopolitically significant.

For sure, it is not the best environment for social democracy to thrive. One the one hand, due to the historical association of the political left with communism, the social democratic ideas have been intensively stigmatised in the public discourse. Moreover, in a heavily securitised environment, it is more difficult to articulate and promote a pragmatic socio-economic platform rather than pursue ideationally intensive political communication. However, under such circumstances, the Eurosceptic forces have also been tamed. Nevertheless, despite somewhat similar conditions, the Baltic social democratic parties took different paths and eventually appeared in different situations.

\section{Social Democrats in Lithuania: struggling with the past}

The Lithuanian Social Democratic Party (LSDP) emerged in 1989 (during Mikhail's Gorbachev's perestroika and glasnost era) as both a part of the pro-independence movement and as a successor of the historic Social Democratic Party founded in 1896. It took its current shape, however, in 2001 when it united with the ex-communist Lithuanian Democratic Labour Party (LDDP). While the original title of LSDP was retained, the ex-communist LDDP as a more significant force prevailed. The first LDDP's leader and later President of Lithuania from 1993-1998 Algirdas Brazauskas became the first chair of the united LSDP and ruled it until his retirement from politics in 2007. He was succeeded by another former LDDP politician and the then Prime Minister Gediminas Kirkilas. Only in 2009, after losing parliamentary elections in the preceding year, did the party congress choose Algirdas Butkevičius, a member of the original LSDP, to take the lead.

While Butkevičius ruled LSDP for eight years, the party course, however, hardly changed during his tenure. To some extent, this path-dependent development of LSDP had been enhanced by restrictions of the party leadership. As Algis Krupavičius, writing in 2013, maintained, 'The party chair or leader heads the party, but he is far from being an omnipotent leader; rather, he is forced by a party statute to act in a collegial manner via the executive LSDP Board, the party praesidium, and the council. The party leader is not an autonomous politi- 
cal force within the LSDP as in other parties' (Krupavičius 2013: 491). An earlier comparative study focusing on the degree of internal party democracy within major Lithuanian parties also established that LSDP had the most democratic procedures to enrol new members, to form local and national party institutions, to elect and control party leadership (Žvaliauskas 2007: 250).

Such a seemingly democratic character of the party is closely related to a relatively large party membership base. While at the end of the 1990s, the original LSDP had only around 3,000-4,000 individual members, after the unification with the ex-communists in 2001 the party membership tripled. During long years in power (2001-2008, 2012-2016) it increased further and gradually outnumbered its closest rivals. In 2012, it reached 22,000 or one-fifth of the total party membership in the country (Krupavičius 2013: 493). After losing elections in 2016 and an eventual split in 2017, the party membership has dropped somewhat to around 17,000-18,000. Nevertheless, LSDP has so far remained the largest party in Lithuania.

Given these numbers, the ratio of party members and their voters fluctuates around $5-10 \%$, which is tantamount to an average size of a political party in Western Europe (Kitschelt 1994). While one has to consider these official numbers with a grain of salt, LSDP has also so far been relatively effective in collecting individual party members' fees and again besting other political parties.

However, this organisational entrenchment of LSDP came with a price. On the one hand, a steady expansion of party membership was primarily achieved via well-developed patronage practices, especially at the municipality level. It significantly contributed to the character of LSDP as the 'party of the power' or a technocratic nomenclature detached from broader societal strata and insensitive to their grievances. On the other hand, it significantly reduced its capacities for strategic adaptability to external challenges in the increasingly volatile political environment. The decentralisation of the internal decision-making process helped maintain relatively powerful electoral machines at the local level. On the same time, it also meant that parties' representatives at the parliament were also largely autonomous and non-accountable to the rest of the party. It greatly complicated circulation of policy ideas within the party and led to the actual freezing of the party establishment.

While few figures coming from the original LSDP (such as Algirdas Sysas and Juozas Olekas) were leaders of national trade unions' associations until the early 2000s, the cooperation with trade unions has always been somewhat limited. On the one hand, the very trade unions have struggled to develop their organisational and lobbying capacities. On the other hand, the Social Democrats have been criticised for a long time for their susceptibility to corporate business interests. Although they have ruled most of the time since 1990, they have done little to challenge an unusually high-income inequality and very low redistribution in comparison with other EU member states. Arguably, the last nail in the 
coffin of the Social Democrats' dominance in Lithuania was the adoption of a liberal and also widely unpopular labour code just before the parliamentary elections in September 2016 (Jastramskis et al. 2018). Despite sharp public criticism from the opposition and the president's veto, the then prime minister and party leader Butkevičius proved to be capable of securing votes needed for passing the legislation. However, it also revealed how little the then LSDP leadership cared for maintaining the ideational credentials of the democratic left.

In this regard, Lithuanian Social Democrats mostly followed their Hungarian and Polish colleagues' path. In both latter cases, their socially conservative right-wing competitors outmanoeuvred the centre-left parties by becoming more left in economic matters than the former. Their increasingly pro-market stance left an open space for right-wing populist parties to appeal to the disgruntled voters from economic peripheries and of lower socioeconomic statuses. Nevertheless, despite more acute income inequality in both Hungary and Poland, Lithuanian Social Democrats, for a long time, had relied on several vital safeguards to avoid such a scenario.

Foremost, due to a high degree of securitisation in the political system, there have so far been fewer opportunities for socially conservative and thus effectively Eurosceptic-inclined parties to emerge. The main centre-right party Homeland Union - Lithuanian Christian Democrats (Tèvynés Sajunga - Lietuvos krikščionys demokratai, TS-LKD) until recently did not shy away from taking conservative positions on specific socio-cultural issues. However, it has been cautious enough not to confront the EU directly and most recently, in the presence of numerous challenges for the EU, has resolutely reinforced its pro-European character (TS-LKD 2018). What is also essential is that it has remained committed to the economic right. Also, both periods when TS-LKD ruled (1996-2000 and 2008-2012) were significantly affected by the external economic crises. Consequently, TS-LKD was forced to pursue austerity policies that significantly undermined its popularity. Against this background, while TS-LKD's electorate is one of the most stable among all Lithuanian parties, prospects for its expansion are limited. Moreover, its potential for making coalitions has also been restricted mainly to liberal centre-right parties. In such circumstances, the Social Democrats could enjoy a somewhat secure pivotal position in the political system. A mixed electoral system, when half of the MPs' seats are distributed in single-mandate districts and another one in a multi-mandate district, was also thought to be beneficial for LSDP and TS-LKD as two major parties.

Nevertheless, LSDP was not immune to challenges from other parties, especially from newcomers challenging the whole political establishment. Despite an economic boom, accession to the EU and NATO and the personal charisma of then prime minister Brazauskas, a new Labour Party founded by tycoon Viktor Uspaskich had already scored a convincing victory in a multi-mandate district in parliamentary elections in 2004. Eventually, Brazauskas exploited a strategic 
advantage of a pivotal LSDP's position in the party system to make a coalition agreement with the Labour Party, which allowed him to keep the post of prime minister. However, it was a strong warning signal that the guarantees for the Social Democrats to dominate in the political system should not be overstated.

It seems, however, that they did not learn this lesson properly, and in the last parliamentary elections it experienced another severe blow - this time from the Lithuanian Farmers and Greens Union (Lietuvos valstiečiu ir žaliuju sajunga, LVŽS). Despite their overall centrist character, the Farmers and Greens deliberately cultivated an image of a people-oriented political party, while in economic terms it sought to accentuate its leftist values. Like the Labour Party, LVŽS essentially is a vertical organization also headed by a tycoon involved in agribusiness, Ramūnas Karbauskis. The form of an 'entrepreneurial party' helped them develop its infrastructure during a relatively short time and promote an image of a party with strong and decisive leadership.

The parliamentary elections in fall of 2016 were disastrous for LSDP. The Farmers and Greens secured 56 of 141 mandates, while LSDP got only 17 seats and ended up in a distant third, also beaten by TS-LKD. Poll surveys did not predict such a convincing victory for LVŽS, and they finished second in the multi-mandate district after TS-LKD. However, in the second round of single-mandate districts, voters evaluated the Farmers and Greens as a viable alternative to both major parties, which eventually determined the outcome of the elections.

These parliamentary elections were also a turning point for LSDP from their previously taken path. In spring 2017, for the first time in the party's history, direct elections of the party chair were organised to include all party members in selecting a new leader. The decision emulated a TS-LKD practice that has been directly electing its leader since 2009. As Butkevičius declined to run in these elections, they were widely perceived as an opportunity for the rejuvenation of its leadership and the whole party. Two young, yet already experienced politicians got into the second round - 37-years-old Vilnius deputy mayor Gintautas Paluckas versus then Minister of Economy Mindaugas Sinkevičius, who was five years Paluckas' junior.

Eventually, Paluckas narrowly won the elections by managing to appeal to ordinary party members with a promise to substantially reform the party and bring back its leftist values. The outcome was a shock to most of the party establishment who were supporting the more moderate candidacy of Sinkevičius, a son of Rimantas Sinkevičius who was an influential LSDP member, parliamentarian and Transport Minister in Butkevičius's 2012-2016 government.

A few months after he took the lead of the party, Paluckas organised a party referendum whether to leave a ruling coalition with the Farmers and Greens. The will of the ranks and files again did not match the preferences of most of the old party elite. In October 2017, based on the referendum, the party council decided to go to the opposition and in such a way to seek to renew its leftist credentials. 
However, 10 out of 17 members of LSDP's parliamentary faction decided to disobey the party decision. Eventually, they left the party and created a new organization - the Social Democratic Labour Party (LSDDP). Notably, the dissenters included both former prime ministers and party leaders Kirkilas and Butkevičius though the latter only joined LSDDP's parliamentary faction. Most of them (with the notable exception of Butkevičius) were originally from LDDP, while the majority of those MPs who followed the party decision came to politics via the original LSDP.

In the wake of the departure of former party leaders, public support for LSDP plummeted further. However, the party got an opportunity to launch a comprehensive both programmatic and personnel renewal. Results of the local and European elections in spring 2019 have shown that the party is gradually regaining its former popularity. The party got the largest share of mayors (15 out of 60) and finished in second place in the European Parliament's (EP) election behind only TS-LKD. In these elections, LSDP not only surpassed the ruling LVŽS but also got the largest number of votes since 2004 .

By the end of 2019, LSDP reached second-place in the poll surveys (receiving around $12 \%$ of popular support) only behind TS-LKD (17\%) while LVŽS got $7 \%$ and fell down to the fourth-place also yielding ground for the Labour party (9\%). Given that the support for the ruling Farmers and Greens at the end of 2016 was around 34\%, their decline over three years had been indeed dramatic (Brunalas 2020).

Although the failure of LVŽS to maintain its initial support after the parliamentary elections in 2016 necessitates a separate analysis, one of the probable reasons for their decline had been a certain degree of their fragmentation. Despite the fact that the very LVŽS party is highly centralised, from the outset of their parliamentary victory its leader Karbauskis had to share powers with their delegated Prime Minister non-partisan Saulius Skvernelis, a popular former Interior Minister in Butkevičius's government. His agreement to lead LVŽS's electoral list was one of the main factors of the Farmers and Greens success in 2016 but also pe-determined a relative fragmentation of their future rule. Party popularity also suffered from the eventual exit of several of its key MPs - mainly due to disagreements with Karbauskis - including the then most popular LVŽS politician and Seimas's speaker Viktoras Pranckietis.

\section{Estonian and Latvian Social Democrats: between Scylla and Charybdis}

A few important reasons allow separating LSDP from its counterparts in the other two Baltic countries. Firstly, post-independent social democratic parties in Estonia and Latvia did not dominate as it had been for a long time in Lithuania. Their party membership has remained rather small, and they have so far never won elections so they could form a government or head a ruling coalition. 
Secondly, ex-communists did not play such a role within the parties as in the case of LSDP. Ultimately, Social Democrats have had to compete with their opponents in the presence of a prominent ethnolinguistic cleavage in both countries.

Estonian and Latvian societies became increasingly heterogeneous as a result of the mass migration of Russophones after the Second World War. In 1989, just before regaining independence, there were respectively around $35 \%$ and $42 \%$ residents who identified themselves as Russians or Russian speakers in Estonia and Latvia. While their proportion eventually decreased sequentially by $6 \%$ and $8 \%$ in 2009 , the ethnic division has remained a defining feature of these political systems. One contributing factor to its salience was that during the Soviet rule there was virtually no integration between the Russian-speaking population and the titular nations. Moreover, the then government did not seek to remediate the situation (Auers 2015: 46-47).

From the outset of transformation, such segregation pushed ethnic Latvians and Estonians to support right and centre-right movements to confront the forces representing the Russian-speaking population. Many Russophones in these countries were in a worse socio-economic position and usually somewhat nostalgic regarding the previous order. Therefore, the movements that claimed to defend their interests were often espousing leftist economic views.

For Latvian and Estonian Social Democrats, it was a double challenge. On the one hand, the very image of the political left was framed as having significant geopolitical and ethnicity-related connotations. It was challenging to popularise social democratic ideas despite the high social costs of the so-called 'shock therapy' economic reforms. On the other hand, Estonian and Latvian Social Democrats were confronted with the dilemma with which side to form coalitions after national and local elections. Their positions on socio-economic issues were similar to the movements supporting the interests of Russophones. However, due to the salience of the ethnic division, they were pressured to participate in coalitions headed by generally pro-business centre-right parties.

To cope with the first part of the challenge, social democratic parties in both countries tried to increase their political and electoral relevancy. For that purpose, they committed to a series of mergers with other parties. The Estonian Social Democrats even strategically agreed to sacrifice their party name for the sake of unity with other like-minded forces.

The founding of the Estonian Social Democratic Party (ESDP - Eesti Sotsiaaldemokraatlik Partei) in September 1990 was the outcome of the unification of three local social democratic groups (the Estonian Democratic Labour Party, the Estonian Social Democratic Independence Party and the Russian Social Democratic Party of Estonia) with the émigré socialist party. Further, ESDP decided to contest the first post-independence elections to Riigikogu in 1992 together with the Rural Centre Party (EMKE) under the name Moderates. This union succeeded in taking 12 mandates in the 101-seat parliament and was invited to 
take part in the government led by Mart Laar and his nationalist-conservative Pro Patria alliance. After a setback in parliamentary elections in 1995, ESDP and EMKE decided to form a united party under the already established Moderates name. Later, the party once again changed its name to the People's Party Moderates, but soon this appeared to be not the most successful move. The party took only $6^{\text {th }}$ place in the 2003 elections (with six mandates) amid widespread criticism that it cannot be treated as left-wing. To address the issue, in 2004 the party decided to bring social democracy back to the title and renamed itself the Social Democratic Party (Sotsiaaldemokraatlik Erakond - SDE) (Pettai and Saharov 2013: 436).

Eventually, such strategic flexibility and openness to electoral alliances and mergers paid off. The party in its different forms and names was not immune to electoral losses and questions about their true political identity. However, they performed rather well in most elections, winning from 10 to 19 seats. The party was frequently invited to participate in forming the government and even had their former leader Toomas Hendrik Ilves elected as the country's president in 2006. The Estonian Social Democrats were criticised for systemic collaboration with right-wing parties, beginning with the first Laar's government in 1992-1994. Nevertheless, they often controlled the Ministry of Social Affairs, which allowed them to carry out essential reforms of the welfare sector. In this regard, they have contributed to the relatively high level of well-being in Estonia in comparison to other ECE countries. Estonia has reached $12^{\text {th }}$ place among $28 \mathrm{EU}$ member states in the latest rankings of the EU Social Justice Index, although their GDP per capita is still below the EU average (Social Inclusion Monitor Europe 2017).

Therefore, it is difficult to agree with Tavits's description of the Estonian social democratic leaders as 'amateur ideologues' who did not bother to create an expansive party network (Tavits 2013). While they might have avoided rather mundane party-building activities, they were quite pragmatic and strategic enough to guarantee a relatively stable party performance. However, they did not dare to cross the line and start cooperating with Savisaar's Centre Party (except a short-lived attempt to work in the Tallinn city council in 2009-2010). Arguably, it significantly contributed to the fact that around 95\% of SDE voters are ethnic Estonians. Despite the efforts of social democratic leaders to spearhead the development of pro-active minority integration policy, Russophones continued to see the Social Democrats as yet another pro-Estonian political force (Pettai and Saharov 2013: 446).

The fate of the Latvian Social Democrats Workers Party (LSDSP) reveals what could have happened if the Estonian Social Democrats had decided to cooperate with the Savisaar's Centre Party. LSDSP was re-founded in December 1989 thanks to a critical role played by the foreign committee of the Latvian Social Democrats in exile. It is therefore considered to be the only political party in Latvia to have 
retained its organizational continuity throughout the Soviet occupation (Ikstens 2013: 471). LSDSP was not initially successful. While quite a few left-wing or populist parties got into the parliament in 1993 and 1995, the LSDSP could not make it through. The situation had changed when it started to cooperate in 1995 with the Latvian Democratic Labour Party (LaDDP) founded by pro-independence communists before finally merging in 1999 under the name of LSDSP. This rapprochement between the two left-wing parties soon bore fruit. In elections in 1998 the joint list of the two parties gained fourteen seats in the 100-strong national parliament. Moreover, in local elections in 2001 LSDSP scored a clear victory. They were the only party to get representation in big Latvian cities and also won enough seats to claim for themselves the post of Riga's mayor.

However, it was a Pyrrhic victory. During negotiations regarding the mayoral position in Riga, the right-wing parties did not want to give this post to LSDSP. They calculated that the Social Democrats would not dare to make a coalition with the 'For Human Rights in United Latvia' (Ikstens 2013: 475), but that is what happened. With the help of the pro-Moscow movement, the then LSDSP leader, former member of LaDDP, Juris Bojārs ensured that his son Gundars Bojārs would become a new mayor of Riga city. Eventually, the public support for the party dropped. Moreover, this move provoked an internal dissent, which ended when a group of MPs of LSDSP protesting against the party leadership left the party in 2002. After these events, LSDSP did not get any seats in the next parliamentary elections and has never recovered from the crisis.

For some time, after the fall of LSDSP, there were no relevant parties in Latvia that would belong to the PES. Eventually, the Social Democratic Party 'Harmony' got such recognition in 2012. The party (founded in 2010) originated from the electoral alliance 'Harmony Centre' formed in 2005, which comprised of several pro-Russian and leftist parties. Most of them were also members of eventually abolished 'For Human Rights in United Latvia'. Ironically, the Latvian Social Democratic Party, founded by the same dissenters who left LSDSP protesting its cooperation with the 'For Human Rights in United Latvia' movement, joined the alliance in 2009. This move helped to legitimise 'Harmony Centre' as a social democratic force. Eventually, it paved the way for founding in 2010 a party that included names from both Harmony and the Social Democratic Party and was accepted into PES. From the outset, however, the new party, led by Riga's Mayor Nils Ušakovs, has been dominated by the 'Harmony' politicians. They ultimately rest their case on the ethnic-linguistic cleavage rather than on the socio-economic platform. The Latvian Social Democrats' strategic errors in forming coalitions and their failure to build a strong party organisation have significantly contributed to the dominance of the ethnic cleavage in Latvia's party politics.

Meanwhile, in Estonia, the ethnic division was less prominent. It was linked with the communist/anti-communist cleavage and to some extent balanced 
by the socio-economic divide. In November 2016, a ground-breaking political experiment was launched. SDE, together with the Pro Patria and Republic Union, decided to make a ruling coalition with the Centre Party. They made such a decision after the latter finally pushed out its long-serving chair Savisaar and replaced him with Jüri Ratas, a politician of the young generation. By taking this step, the Conservatives and the Social Democrats broke the coalition treaty with the pro-business Reform Party that had been in the government since 1999 and led the minister cabinets for most of the time.

On the one hand, such a government reshuffle has signalled that the ethnic and communist/anti-communist divisions are becoming less prominent. On the other hand, it was a risky move, which might have cost SDE. Its popularity quite sharply dropped at the beginning of 2017 and did not recover till parliamentary elections in March 2019. Eventually, SDE lost five of their previous 15 seats in a new 101-member Riigikogu and fell to (the last) $5^{\text {th }}$ place. Furthermore, the Social Democrats lost their former dominance in poorer South-East Estonia to EKRE. This right-wing populist and Eurosceptic party has significantly increased its share of votes and with 19 mandates took third place in the new parliament only behind the Reform (34 seats) and the Centre (26 seats) Parties.

Such poor SDE results prompted the resignation of its chair Jevgeni Ossinovski. Among the reasons of the defeat, the observers singled out a lack of appealing candidates as well as a failure to convey its key messages (Toots 2019). Arguably, the permanent role of a minor coalition partner in ideologically different governments hindered SDE from providing a clear and convincing vision in the last parliamentary elections. Despite this loss, the party bounced back in the EP elections in May 2019. SDE headed by Marina Kaljurand, a former Foreign Affairs minister and candidate for president, came in second place (just behind the Reform party) and won two out of the country's six MEP seats. Considering that both the Centre Party and EKRE performed worse, Social Democrats in Estonia have so far retained their political relevance.

\section{Conclusions}

The analysis has supplemented the current literature that has so far mostly focused either on external challenges to understand the political fortunes of Social Democrats in ECE. It has demonstrated that strategic choices made by leadership might be of crucial importance for determining party development in future.

Choices of particular importance have involved the politics of mergers and coalition-building. From the outset, Social Democrats in all three Baltic countries were actively engaging in seeking allies, firstly, to survive, and, secondly, to get access to power. However, these alliances usually entailed tensions between the goals of power-seeking and guarding the profile of a left-oriented party. In highly securitised Baltic political systems, Social Democrats took significant 
risks of severely damaging their reputation by trespassing certain identity boundaries.

In some cases, such moves helped to solidify the parties and paved the way to power. Despite apparent controversies, both Latvian and Lithuanian Social Democrats merged with the ex-communist forces at the turn of the century to become stronger and more competitive in volatile party politics. Estonian Social Democrats did not follow suit. Nevertheless, they also accomplished several mergers, temporarily renamed themselves and pursued cooperation with the prevailing centre-right parties.

Such mergers, however, usually came with a price. For the genuine Social Democrats who aimed to restore the inter-war tradition, the collaboration with organisationally endowed and inherently managerial ex-communists largely meant relinquishing the front positions to the latter in the joint structures. For their part, the 'pragmatic' ex-communist leaders of the merged units, such as Bojārs and Brazauskas, were not so scrupulous to live up to the parties' claimed ideals.

The decision by Bojārs to install his son as Riga's mayor thanks to the ruling coalition with pro-Russian forces proved to be fatal for LSDSP. Facing similar dilemmas in an ethnically divided society, Estonian Social Democrats took a different route and avoided such a scenario. Nevertheless, the enduring cooperation with more powerful liberals and conservatives had been increasingly raising questions about their leftist credentials. This pressure at least partially explains why SDE in 2016, albeit not without significant risk, decided to switch the sides.

In the case of Lithuania, the consolidation of the original LSDP and the ex-communist LDDP allowed a dominant power to emerge that has, however, done little to tackle inequality and other social malaise in the country. When an attractive centrist-populist alternative of a 'business-firm party' LVŽS emerged, LSDP suffered a major setback in parliamentary elections in 2016. In the following year, it led to the direct election of new party leader Paluckas for the first time in party's history. It eventually resulted in the organisational overhaul and the exodus of key political figures from the ex-communist LSDP wing.

A post-2016 development of LSDP reflects a rather successful adaptation to changed patterns of competition that increasingly favour a more centralised and presidentialised party organisation. Furthermore, in comparison to Fidesz and PiS, Karbauskis's Farmers and Greens were neither fully centralised nor enjoyed sweeping legislative powers, which made LSDP efforts to rebound more likely to succeed.

It is necessary to further explore how the recent LSDP developments are related to the fact that the merger with the ex-communists happened only in 2001, which separates it from 'paradigmatic' Polish and Hungarian cases where the ex-communists prevailed almost from the outset of democratisation. In addition, considering that strategic political choices by parties and their leaders (either miscalculated or eventually successful) can make the difference how 
parties develop in future, one has to investigate intra-party processes in the Baltic and other ECE social democratic movements more closely. Likewise, it is worth it to research how they engage their supporters and members to build up resilience against numerous challenges of today.

\section{References}

Auers, D. (2015): Comparative Politics and Government of the Baltic States: Estonia, Latvia and Lithuania in the 21st Century. Basingstoke and New York: Palgrave Macmillan.

Ágh, A. (2018): The long road from Neoliberalism to Neopopulism in ECE: The social paradox of neopopulism and decline of the Left. Baltic Journal of Political Science (7-8): 6-26.

Bozóki, A. and Ishiyama, J.T., eds. (2002): The Communist Successor Parties of Central and Eastern Europe. New York: Sharpe.

Brunalas B. (2020): „Naujausi partijų reitingai: konservatorių nedžiugina, o valstiečiams tragiški". $<$ https://www.delfi.lt/news/daily/lithuania/naujausi-partiju-reitingai-konservatoriu-nedziugina-o-valstieciams-tragiski.d?id=83264167>. Accessed January 14, 2020.

Bucur, C. and McMenamin, I. (2015): „Poland: The Presidentialization of Parties in a Young Democracy", In: Passarelli G., ed. The Presidentialization of Political Parties: Organizations, Institutions and Leaders. Basingstoke: Palgrave, 107-123.

Cabada, L. (2015): Changes in Mutual Relations between Czech Social Democrats and Communists after 2000 and Strengthening of Anti-Communism in Czech Society and Politics. Politické vedy / Political Sciences, 18(4): 8-31.

Cabada, L., Hloušek, V. and Jurek, P. (2014): Political Parties in East Central Europe. Lanham: Lexington Books.

Cook, L.J., Orenstein, M.A. and Rueschemeyer, M., eds. (1999): Left Policies and Social Policy in Postcommunist Europe. Boulder, CO: Westview Press.

Coppieters, B., Deschouwer, K. and Waller, M., eds. (1994): Social Democracy in a Post-Communist Europe. Ilford and Portland: Frank Cass \& Co. Ltd.

Curry, J.L. and Urban, J.B., eds. (2003): The Left Transformed in Post-Communist Societies: The Cases of East-Central Europe, Russia, and Ukraine. Lanham: Rowman \& Littlefield Publishers.

Dauderstädt, M. (1999): Troubled Transition: Social Democracy in East Central Europe. Bonn: Friedrich Ebert Stiftung.

Dauderstädt, M. (2005): The Communist Successor Parties of Eastern and Central Europe and European Integration. Journal of Communist Studies and Transition Politics 21(1): 48-66.

De Waele, J.-M. and Soare, S. (2011): The Central and Eastern European Left: A Political Family under Construction. In: J. Cronin, G. Ross and J. Shoch, eds. What's Left of the Left: Democrats and Social Democrats in Challenging Times. Durham: Duke University Press, 290-318.

Enyedi Z. (2005): The role of agency in cleavage formation. European Journal of Political Research, 44: 697-720. 
Gerrits, A. W. M. (2002): The Social Democratic Tradition of East Central Europe. East European Politics and Societies 16(1): 54-108.

Greskovits, B. (2015): The Hollowing and Backsliding of Democracy in East Central Europe. Global Policy 6(1): 28-37.

Grzymala-Busse, A. (2002): Redeeming the Communist Past. Cambridge: Cambridge University Press.

Grzymala-Busse A. (2018): Victims of Their Own Success: The Paradoxical Fate of the Communist Successor Parties. In: Loxton J. and Mainwarring S, eds. Authoritarian Successor Parties, New York: Cambridge University Press, 145-174.

Grzymala-Busse A. (2019): Hoist on Their Own Petards? The Reinvention and Collapse of Authoritarian Successor Parties. Party Politics 25(4): 2019: 569-582.

Hloušek V. (2014): Is the Czech Republic on its Way to Semi-Presidentialism? Baltic Journal of Law \& Politics 7(2): 95-118.

Hloušek, V. and Kopeček, L. (2010): Origin, Ideology and Transformation of Political Parties East-Central and Western Europe Compared. Abingdon and New York: Ashgate Publishing.

Hloušek, V. and Kopeček, L. (2017): Entrepreneurial Parties: A Basic Conceptual Framework. Czech Journal of Political Science 24(2): 83-91.

Hloušek V. and Kopeček L. (2019): How to run an efficient political machine: the billionaire Andrej Babiš and his political-business project. Politics in Central Europe 15(1): 35-54.

Holmes, M. and Lightfoot, S. (2011): Limited Influence? The Role of the Party of European Socialists in Shaping Social Democracy in Central and Eastern Europe. Government and Opposition 45(1): 32-55.

Hopkin, J. and Paolucci, C. (1999): The business firm model of party organisation: Cases from Spain and Italy. European Journal of Political Research 35: 307-339.

Hough, D., Paterson, W.E. and Sloan, J., eds. (2006): Learning from the West: Policy Transfer and Programmatic Change in the Communist Successor Parties of East Central Europe. London: Routledge.

Ikstens, J. (2013): Latvia. In: J.-M. De Waele, F. Escalona and M. Vieira, eds. The Palgrave Handbook of Social Democracy in the European Union. Basingstoke and New York: Palgrave Macmillan.

Jastramskis, M., Kavaliauskaitė, J., Morkevičius, V., Petronytė-Urbonavičienè, I. ir Ramonaitè, A. (2018): Ar galime prognozuoti Seimo rinkimus? Trijų kūnų problema Lietuvos politikoje. Vilnius: Vilniaus universiteto leidykla.

Keman, H. (2017): Social Democracy: A Comparative Account of the Left-Wing Party Family. London and New York: Routledge.

Kitschelt, H. (1994): The Transformation of European Social Democracy. Cambridge: Cambridge University Press.

Kopeček L. (2016): „I'm paying, so I decide“: Czech ANO as an Extreme Form of a Business-Firm Party. East European Politics and Societies 30(4): 725-749. 
Krupavičius, A. (2013): Lithuania. In: J.-M. De Waele, F. Escalona and M. Vieira, eds. The Palgrave Handbook of Social Democracy in the European Union. Basingstoke and New York: Palgrave Macmillan.

Kudrnáč A. and Petrúšek I. (2018): Czech Republic: Political development and data for 2017. European Journal of Political Research Political Data Yearbook. 1-11.

Mair, P. (2013): Ruling the Void. The Hollowing of Western Democracy. London: Verso.

Malova D. (2013): Slovakia. In: J.-M. De Waele, F. Escalona and M. Vieira, eds. The Palgrave Handbook of Social Democracy in the European Union. Basingstoke and New York: Palgrave Macmillan, 550-574.

Orenstein, M.A. (1998): A genealogy of Communist successor parties in East Central Europe and the determinants of their success. East European Politics and Societies 12(3): 472-99.

Panebianco, A. (1988): Political Parties: Organization and Power. New York: Cambridge University Press.

Passarelli G. (2015): Parties' Genetic Features: The Missing Link in the Presidentialization of Parties. In: Passarelli G., ed. 2015. The Presidentialization of Political Parties: Organizations, Institutions and Leaders. Basingstoke: Palgrave. 1-24.

Perottino M. and Polášek M. (2013): Czech Republic. In: De Waele J.-M., Escalona F., Vieira M., eds. The Palgrave Handbook of Social Democracy in the European Union, Basingstoke \& New York: Palgrave Macmillan. 416-433.

Pettai, V. and Saharov, J. (2013): Estonia. In: J.-M. De Waele, F. Escalona and M. Vieira, eds. The Palgrave Handbook of Social Democracy in the European Union. Basingstoke and New York: Palgrave Macmillan.

Poguntke T. and Webb, P. D. (2018): Presidentialization, Personalization, and Populism: The Hollowing Out of Party Government. In: Cross, W. P., Katz - R.S., Pruysers S. (eds.), 2018. The Personalization of Democratic Politics and the Challenge for Political Parties, Oxford: Oxford University Press. 181-196.

Ramonaitè, A., Jastramskis, M., Kavaliauskaitè, J., Nevinskaitè, L. ir Žiliukaitè, R. (2014): Kaip renkasi Lietuvos rinkejjai? Idejjos, interesai ir jvaizdžiai politikoje. Vilnius: Vilniaus universiteto leidykla.

Saarts, T. (2011): Comparative Party System Analysis in Central and Eastern Europe: The Case of The Baltic States. Studies of Transition States and Societies 3(3): 83-104.

Schmidt, I., ed. (2016): The Three Worlds of Social Democracy: A Global View. London: Pluto Press. Social Inclusion Monitor Europe (2017): Social Justice in the EU - Index Report 2017. Bertelsmann Stiftung.

Tarrow, S. (2010): The strategy of paired comparison: toward theory of practice. Comparative Political Studies 43(2): 230-259.

Tavits, M. (2013): Post-Communist Democracies and Party Organization. Cambridge: Cambridge University Press.

Toots, A. (2019): 2019 Parliamentary Elections in Estonia. Riga: Friedrich Ebert Stiftung. 
TS-LKD (2018): Declaration: We believe in Europe. <https://tsajunga.lt/wp-content/uploads/2018/05/TS-LKD-European-Declaration_2018-05-12-EN.pdf>. (7 July 2019).

Vachudova, M.A. (2015): The positions and fortunes of social democratic parties in East Central Europe. In: M. Keating and D. McCrone, eds. The Crisis of Social Democracy in Europe. Edinburg: Edinburgh University Press. 47-67.

Žvaliauskas, G. (2007): Ar partijos Lietuvoje yra demokratiškos? Kaunas: Technologija.

Liutauras Gudžinskas is Associate Professor at the Institute of International Relations and Political Science, Faculty of Philosophy, Vilnius University/Lithuania. Email: liutauras.gudzinskas@tspmi.vu.lt. 